\title{
New Challenges for Online Learning: Literature, History and Film Studies
}

\author{
Luís Miguel Cardoso
}

\begin{abstract}
Education today faces not only the challenge of technology, but the challenge of digital teaching and the growing change that characterizes today's students. Universities need to provide very varied skills for professions that will only exist in 2030, for example, which requires constant research work on teaching methodologies, skills for students and adapting Education to the challenges of the online system. These changes affect all areas of teaching, including literary and film studies that have to be adapted to this reality. This transformation turns out to be very positive because cinema allows to stimulate many other areas of knowledge.
\end{abstract}

Keywords - Portuguese Literature and History, Online learning

\section{INTRODUCTION}

Today's society is a huge challenge for teachers and educators, since the vertigo of information and technologies, social and cultural transformations, as well as the constant evolution of the student's profile make the teaching-learning experience unequivocally a place and time of permanent change. On the one hand, the education system must keep up with these changes, so that the study plans remain relevant, appropriate and updated, the methodologies used reflect modernity and the teachers are trained and master the latest literacies and pedagogical practices. On the other hand, students, immersed in the worlds of technologies, information multiplatforms and multimedia, encourage Education to embrace new itineraries of pedagogical innovation, so that the teaching-learning process stays focused on the whirlwind of times. As the OCDE states:

The concept of competency implies more than just the acquisition of knowledge and skills; it involves the mobilisation of knowledge, skills, attitudes and values to meet complex demands. Future-ready students will need both broad and specialised knowledge. Disciplinary knowledge will continue to be important, as the raw material from which new knowledge is developed, together with the capacity to think across the boundaries of disciplines and "connect the dots". Epistemic knowledge, or knowledge about the disciplines, such as knowing how to think like a mathematician, historian or scientist, will also be significant, enabling students to

Luís Miguel Cardoso, Polytechnic Institute of Portalegre and Centre for Comparative Studies of the University of Lisbon (Portugal) extend their disciplinary knowledge. Procedural knowledge is acquired by understanding how something is done or made - the series of steps or actions taken to accomplish a goal. Some procedural knowledge is domain-specific, some transferable across domains. It typically develops through practical problem-solving, such as through design thinking and systems thinking. Students will need to apply their knowledge in unknown and evolving circumstances. For this, they will need a broad range of skills, including cognitive and metacognitive skills (e.g. critical thinking, creative thinking, learning to learn and self-regulation); social and emotional skills (e.g. empathy, self-efficacy and collaboration); andpractical and physical skills (e.g. using new information and communication technology devices). The use of this broader range of knowledge and skills will be mediated by attitudes and values (e.g. motivation, trust, respect for diversity and virtue). The attitudes and values can be observed at personal, local, societal and global levels. While human life is enriched by the diversity of values and attitudes arising from different cultural perspectives and personality traits, there are some human values (e.g. respect for life and human dignity, and respect for the environment, to name two) that cannot be compromised. (OCDE, 2018, p. 5)

Nowadays, our biggest challenge is to promote critical thinking with Online Teaching. Education must find in online technology resources to accomplish what OCDE defines as priorities:

Education needs to aim to do more than prepare young people for the world of work; it needs to equip students with the skills they need to become active, responsible and engaged citizens. (...) Students will need to apply their knowledge in unknown and evolving circumstances. For this, they will need a broad range of skills, including cognitive and meta-cognitive skills (e.g. critical thinking, creative thinking, learning to learn and self-regulation); social and emotional skills (e.g. empathy, self-efficacy and collaboration); and practical and physical skills (e.g. using new information and communication technology devices). The use of this broader range of knowledge and skills will be mediated by attitudes and values (e.g. motivation, trust, respect for diversity and 
virtue). The attitudes and values can be observed at personal, local, societal and global levels. While human life is enriched by the diversity of values and attitudes arising from different cultural perspectives and personality traits, there are some human values (e.g. respect for life and human dignity, and respect for the environment, to name two) that cannot be compromised. (OCDE, 2018)

With the COVID-19 pandemic, education used distance learning technologies to stay active and to stay focused. With distance learning, we need to find pedagogical innovation strategies that can attract the attention of students, assist in the fulfillment of teaching plans and achieve better results. Cinema has long ceased to be just an illustration of the themes of the classes and has become a valuable educational tool. Nowadays, cinema can be taken to the classroom and its pedagogical functions can be very usefull for all teachers. The potential of cinema is highlighted by Tofur:

Audiovisual resources have an undeniable effect on the experiences of teenagers that constitute the cognitive domain (Fisch et al, 1997). Movies are audiovisual sources of information that can directly affect the perception and understanding (Arroio, 2010). Our desires, beliefs, and perceptions can be affected by the movies (Kavan \& Burne, 2009). In this regard, as a media element, the movies are powerful instructional environments (English \& Steffy, 1997). Cultural works that are structured by forming our understanding of organizational and social life can be seen as recreational activities in which the reality is reflected (Huczynski \& Buchanan, 2004). A subject or a message aimed be expressed through the movies can be effectively conveyed in an audiovisual way (Demirtaş, 2011). Nowadays, the rapid growth of the cinema sector has increased the importance of the use of cinema as a tool in the transfer of knowledge and in education. Very complex and comprehensive issues can be delivered to the masses through cinema. Movies serve as a tool for the transmission of all kinds of scientific and behavioral information (Birkök, 2008). Movies can be used as a tool in education, or education can be processed in scenarios within the scope of a purpose (Yurdigül, 2014). (2018, p. 391)

Cinema can be a powerful didactic tool in numerous workshops and different educational levels, leaving the teacher to choose the film and its operation, combining the analysis and the mission, taking into account the curriculum, the learning objectives and the characteristics of the student. Films function as a mediated intervention in relation to reality, requiring students to have a critical and grounded view of the audiovisual product, allowing an analysis of the film and its semiotic and symbolic content, endowing the individual with increasingly diverse skills to understand current social and cultural changes. As Moreira e Ferreira (2016) wrote:
Since its invention, the cinematographic language, more than an aesthetic object with its own specificities, has been a formative and educational language. However, it has often been read in a superficial and subjective way, de-characterizing its potential as a language of knowledge. Like reading a book, enjoying a film requires a minimum of information about different aspects of its language and the means used for its analysis. Performing a filmic reading of the language of cinema implies not only the deconstruction of the video and its subsequent reorganization, giving it meanings previously not perceived, but also, the approximation of a set of complex and comprehensive knowledge on different analytical approaches and knowledge about your language. Indeed, cinema has been increasingly used as a didactic resource in an educational context, because it effectively has an inventive language and a narrative composed of almost unlimited themes and content. To educate for film reading, in this context, means to be sensitized, to know how to sensitize; train the student through experimentation and involve him in the entire teaching-learning process. Such training will be the first step to combat a certain distance from the school in relation to cinema. Providing teachers with means to consciously access films is a fundamental step towards moving from instrumentalizing cinema to understanding its specificity and importance. Only in this way will it be possible to rehearse the training of the students themselves, promoting the viewing of films of various origins and styles, leading to knowledge and analysis of the image, provoking debate in the critical sense, fostering sensitivity and creativity, broadening horizons and progressively investing in an individual with qualifications for democratic citizenship. (2016, p. 8)

Taking into account the huge potential of cinema as a didactic resource and source of pedagogical innovation, we developed a teacher training workshops, which had the following objectives:

Thinking Cinema in tune with the Domains of Curricular Autonomy and Essential Learning, with a view to developing the areas of competence registered in the Student Profile at the end of compulsory schooling; Integrate Cinema in interdisciplinary work and / or curricular articulation, favoring practical and / or experimental work and the development of research, relationship and analysis skills; Use cinema as a strategy for the discovery and understanding of the self, the other and the world; Analyze films, considering aesthetic, technical, semiotic and significant topics.

The theme of the course, centered on teaching through film, included several links to literature, creating projects of dynamism in the area of literary studies, connected to film studies, mediated by distance education technology. Let's see an example of this work, proposed by a History teacher, centered on the film 1917.

Director Sam Mendes, inspired by the experience of his Portuguese descendant grandfather Alfred Mendes, explores 
the theme of war experienced by two British soldiers, in the middle of the trenches, on the western front, during the First World War. The year 1917, which gives the film its title, was a decisive milestone in the evolution and outcome of this war, initially local and regional, but which went global. It marks the turning point of the unprecedented development of the First World War (1914/1918) that dragged on in time.

It is on April 6, 1917 that the film begins, in the midst of "trench warfare". This fact leads us to the entry of the USA into the conflict with all military power, in armament and human contingent, tipping the scales for the Allied bloc, bringing hope, the light of victory and the humiliating, punishing defeat. German. It was the most arduous and destructive phase, challenging all the limits of the human being's courage, resilience and empathy towards his fellow man with a desolate and overwhelming impact on Europe's economy, demography and society, the main theater of war.

On April 6, 1917, Allied air reconnaissance noted that the German army withdrew from a section of the Western Front in northern France, but is not retreating. It made a strategic withdrawal to the new Hindenburg Line, where it is expected to attack the British with artillery. In the British trenches, with the field phone lines cut, two young British soldiers, Corporal Blake and Schofield, a Somme veteran, are tasked with General Erinmore to deliver a message to Colonel Mackenzie of the Devonshire Second Battalion Regiment located few hours away. Mackenzie is preparing to attack the German army in force, as he is unaware that the German withdrawal was a trap. Indeed, if Mackenzie went ahead with his plans, 1600 British soldiers would be on the verge of losing their lives, including Lieutenant Joseph Blake, the older brother of Corporal Blake.

It reveals itself as an epic war film that, with a simple plot, expands the interest in the cast of famous celebrities of reference, who give life to the characters. In this film, emotion, memory and history intertwine.

In the face of destruction, which generates human cruelty in the struggle for survival, we are guided by a narrative that values the meaning of the human dimension weakened in its physical and psychological integrity, values and principles, but which also moves us and unites the main characters Blake (Dean-Charles Chapman) and Schofield (George MacKay) cables.

In "1917", the window opens that allows us to look at a rural and peaceful landscape, where silence and peace reign. This environment contrasts with the unprecedented horror of war as soldiers walk the rails to the front line. In the beginning, both appear immersed in the warrior's well-deserved rest, in silence, sleeping next to a huge tree.

The narrative ends as it begins: a green field, silence, peace. At the end of the journey, the surviving soldier fulfilled the risky mission from which I left almost unhurt and humanly strengthened. It rests next to a huge tree, where silence surrounds it. Open the box of memories. He removes the beloved female portraits that he carefully kept with him along the arduous path populated by sadness, stories, memory, longing, order and chaos, resilience.

History and fiction are interwoven reinforced by the techniques adopted in production. They show us the events through two great sequential plans, giving us the feeling that the editing of the film never undergoes cuts, giving an extreme realism to the film.

Indeed, "1917" can be considered a source of historical knowledge, since life in the trenches and total destruction along the path traveled, incessantly and uninterruptedly, by the young soldiers have been reconstructed. These advance quickly in the fight against time between enemy trenches, risking their lives for the "no man's land" in a peace mission contained in a paper missive exchanged between high military ranks.

The main objectives of this work were:

- Improve learning, enhancing autonomous and free learning;

- Increase observation, critical spirit and historical multiperspective, problematizing the acquired knowledge;

- Extend the study of history, articulating the film narrative with diverse sources, literary text, historical and / or historiographic text and photography;

- Promote historical knowledge, using cinema as a way to discover the past;

- Understand the Present through knowledge of the Past, relating to local and national history, namely the participation of Portugal in the First World War;

- Valuing human dignity and human rights, recognizing the importance of citizenship values for the formation of a civic conscience and responsible intervention in democratic society. With this activity, the following learning outcomes are expected:

1. That the realism contained in the film facilitates, on the one hand, a reconstitution and approximation to the Past, with a view to a distant reality in time.

2. May it be a path of search, discovery and adventure that enhances the proactive construction of learning, guiding students towards self-reflection, critical thinking, sharing, communication of ideas taken from the interpretation of the film's message.

3. That increases the interest to question and understand the world based on the humanistic and civic perspective, valuing the human being's capacity to overcome, who in the face of the adversities of war is moved, sympathized, cries, laughs, misses and fights .

4. That it proves to be a contribution to revive the collective memory that values historical knowledge as a source of teaching for the Present and guarantees the safeguarding of peace and humanistic values.

We discovered that teachers could work on literary topics in their online classes, using cinema as an innovative pedagogical resource and creating connections, that is, in terms of literary and cinematographic narratology, which 
allowed to maintain the teaching of literature in connection with cinema, which makes this online dynamic a great example of success. Various topics and novels from Portuguese writers and world literature were studied, as well as films related to the chosen themes, and it was found that the students reacted very well to this connection. We conclude that the use of online education has overcome many of the difficulties imposed by COVID-19 and has created horizons for collaboration and pedagogical innovation between literary studies, history and film studies

\section{REFERENCES}

[1] Moreira, J. \& Ferreira, V. (2016) Cinema e Educação. Convergências para a formação cultural, social e artística. Santo Tirso: White Books

[2] OCDE (2018) The future of education and skills Education 2030. Paris: OCDE

[3] Tofur, S. (2018). Use of Educational Movies in Classroom Management Courses: A Metaphorical Study. Turkish Online Journal of Qualitative Inquiry. 9. 389-411. 10.17569/tojqi.423738

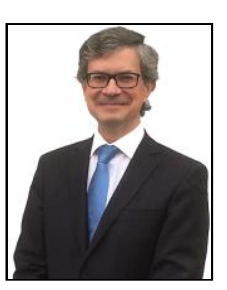

L. Cardoso was born in Viseu (Portugal) in 1969. After concluding the Humanities degree at the Catholic University in 1991, he concluded a Master in Classic Literatures at Coimbra University, in 1996. In 2007 he concluded his PhD in Modern Languages and Literatures at Coimbra University (Portugal). After teaching for four years in secondary schools, he began teaching at the Polytechnic Institute of Viseu in 1995 until 2008, when he moved to the Polytechnic Institute of Portalegre as Adjunct Professor. He was elected Dean of the School of Education and Social Sciences in 2010 until february 2018, completing the two mandates permitted by law. Since 2015 until May, 2018, he was also President of ARIPESE - the Association for Reflexion and Intervention in Higher Schools Polytics. Main interests in teaching and investigation include Science and Communication Languages, Literature and Cinema, and Management of Higher Education Universities. In 2016, he published Literature and Cinema: the look of Janus. Vergílio Ferreira and the space of the unspeakable. Prof. Dr. Cardoso was the national coordinator for the Bologna Process in Polytechnics in Media and Communication Sciences. He is a member of several international organizations concerning Education, Communication, Comparative Literature, Narratology, Film Studies and Higher Education Management and reviewer of several international journals. He has published several papers in national and international journals with peer review and is a member of $\mathrm{C} 3 \mathrm{i}$ - Polytechnic Institute of Portalegre and of the Center for Comparative Studies of the University of Lisbon. 